\title{
Putin's Domestic Policy: Its Implications for National Security
}

\author{
Gennady Chufrin ${ }^{1}$
}

\section{Introduction}

The first president of Russia, Boris Yeltsin, will go down in history as the man who spearheaded a coalition of diverse political forces to dismantle the Soviet Union from within and bring down the Soviet ideological and political systems. However, Yeltsin failed to lead post-Soviet Russia towards social stability and economic progress. Instead, one of the most perceptive studies of Yeltsin's rule points out that he left behind him a society disillusioned with politics and politicians, a greatly weakened national economy, and armed forces in a state of near collapse. ${ }^{2}$ By the end of the 1990s Russia found itself on the brink of complete national disaster. The country was in desperate need of a new generation of politicians "with a sense of mission, national pride, and the desire to build a new and civilized Russia."

In the public mind, Vladimir Putin became identified as just such a politician, even though he entered the national arena only when he was appointed as Russia's new Prime Minister in August 1999. At that time, he was completely untested as a political leader on any major national issue. In fact, he was barely known outside the rarefied world of intelligence and security services, where he was Director of the National Security Service (FSB). Putin was confirmed in his new position by the Russian parliament without difficulty, but this happened largely because at that time he was considered to be no more than a caretaker of governmental affairs during the period prior to upcoming parliamentary and presidential elections.

Putin became popular on the national scale in his own right very quickly-a process that can be dated from his address to the Federal Assembly in the middle of September 1999, when he demanded a hard-line approach towards the separatist rebellion in Chechnya. His popularity as a determined leader continued to soar after the Russian army re-entered Chechnya and avenged its humiliating defeat in the 1994-96 campaign. On the eve of 2000, Vladimir Putin became Acting Russian President after Boris Yeltsin stepped down in his favor. Three months later, Putin won the presidential election, receiving almost $53 \%$ of the popular vote. Almost two years into the first term of his presidency, he remains

\footnotetext{
${ }^{1}$ Professor Gennady Chufrin is a Project Leader at the Stockholm International Peace Research Institute.

${ }^{2}$ See Lilia Shevtsova, Yeltsin's Russia: Myths and Realities, Washington, D.C.: Carnegie Endowment for International Peace, 1999.

${ }^{3}$ Ibid, p. 292
} 


\section{THE QUARTERLY JOURNAL}

the most popular national Russian politician, with a public approval rating almost constantly above $60 \%$. This strong popularity has given Putin a unique opportunity to address a number of domestic issues in a very forceful and consistent way. It has allowed him to use a flexible (and sometimes daring) approach in dealing with major challenges and threats to national and international security.

A list of challenges and threats, as well as potential responses to them, was formulated in the revised Concept of National Security approved by Vladimir Putin in January 2000, when he was still Acting President. ${ }^{4}$ Among domestic threats, three were identified as having a particularly high priority. First, the threat that the Russian Federation would transform into a loose confederation or even disintegrate was seen as most dangerous. Second, a threat to security was perceived from the mounting social tensions in Russian society. Third, the Russian state was threatened by the rapid deterioration in law and order in the country.

Vladimir Putin, having cultivated his image as a strong leader working to re-establish Russia as a great power, pledged to strengthen the Russian state, to achieve national reconciliation and consolidation in society, and to bring order based on the rule of law. He argued that only through achieving these goals would it be possible to strengthen the basis of national security and create a favorable climate for social and economic progress in the country.

This article will analyze the main directions of Putin's domestic national security policy and will offer conclusions regarding its achievements and failures as well as possible implications for domestic security.

\section{Strengthening federal government at the center}

At the very start of his tenure, Vladimir Putin stated that in order to overcome the current national crisis - the most serious one faced by Russia in its modern history-it needed a strong state supported by a united nation. In defining a strong state he drew on traditions within Russian society that see a strong state as "a source and guarantor of law and order and both as an initiator and main driving force of all changes." ${ }^{5}$ Efforts to strengthen the Russian state stood at the center of the administrative and constitutional reforms initiated by Putin over the last two years. In implementing this policy, the most noticeable progress was achieved in the re-establishment of the priority of federal laws over regional legislation. This period was also characterized by a partial redistribution of power from regional authorities back to the federal center; several federal laws were adopted in 200001 curtailing the almost unlimited powers acquired by regional governors and the presidents of the constituent ethnic republics of the Russian Federation during the previous decade. Over 3,500 legal acts that had been adopted by various

\footnotetext{
${ }^{4}$ See Diplomaticheskyi Vestnik 2 (Moscow, February 2000): 3-13

5 Interfax, Moscow, 26 February 2000.
} 
regional authorities were found to be in direct contravention of the Federal Constitution, and most of them were either abrogated or brought in compliance with federal laws. In his annual address to the Federal Assembly in April 2001, Putin claimed that this policy had helped his government to implement the strategic task of strengthening the state and halting its disintegration.

Those achievements, however, would prove neither sufficient nor sustainable unless some basic constitutional provisions were also changed. One such provision was the status of the Federation Council-the upper chamber of the Federal Assembly. Its members, including all governors and presidents of republics, were not elected by popular vote but were instead represented there ex officio. They enjoyed constitutional rights to amend bills already passed through the State Duma, the lower chamber of the Federal Assembly, to send them back for reconsideration, or to delay their adoption into law. There were many instances when these rights were used by members of the Federation Council to pursue narrow regional interests to the detriment of the national ones. On the initiative of President Putin, a special session of the State Duma approved a new procedure for forming the Federation Council in July 2000, and empowered the Russian President to dismiss its members. ${ }^{7}$ Some functions of the Federation Council began to be transferred to the newly formed State Council that has the status of an advisory body to the President.

Not surprisingly, Putin encountered stiff opposition to his reforms from several regional leaders. Yegor Stroyev, speaker of the Federation Council, termed a co-existence of the Federation Council and the State Council, with the latter taking over more and more functions of the former, as "a violation of the system of power" and "unconstitutional." The presidents of some of the ethnic republics were the most vocal in their disagreement. The leader of Tatarstan, Mintimer Shaimiev, strongly suspected that the reforms initiated by Putin would eventually deprive Tatarstan of a large part of its autonomy from the center, which it gained in the turbulent 1990s following the advice of President Yeltsin to "take as much sovereignty as you can swallow." Tatarstan not only continued to refuse to sign the 1992 Federation Treaty, but also insisted on preserving its special status as an associated member of the Russian Federation that was recorded both in its own constitution and in the 1994 power-sharing agreement with Russia? The leaders

\footnotetext{
${ }^{6}$ President Vladimir Putin's Annual Address to the Federal Assembly of the Russian Federation, Moscow, April 3, 2001 ( http://www.mid.ru April 4, 2001).

7 O. Tropkina, "Zakon o formirovanii SF prinyat, teper' delo za prezidentom” (Law on forming the Federation Council is adopted, now it's up to the President) Nezavisimaya gazeta, 20 July 2001.

${ }^{8}$ Radio Free Europe/Radio Liberty (RFE/RL) Newsline vol.5, no.172, part 1 (11 September 2001).

${ }^{9}$ S. Sergievsky, "Tatarstan ne sobiraetsya otkazyvat'sya ot suvereniteta, no predlagaet etogo ne pugat'sya" (Tatarstan has no intention to revoke its sovereignty but proposes not to be frightened by this) Nezavisimaya gazeta, 1 March 2001.
} 
of Chuvashia, Kalmykia, Bashkortostan, and Ingushetia were also openly critical of Putin's reforms.

If opposition to the federal center from such large and relatively affluent republics with predominantly Muslim population as Tatarstan or Bashkortostan were to assume more radical forms, the efforts undertaken by Putin to re-establish the rule of the federal law throughout the country would be completely wasted. The possible escalation of conflict with the ethnic republics, especially with the larger and more important of them, over their constitutional privileges would revive the threat of the disintegration of the Russian Federation along ethnic (and confessional) lines that Putin declared to have been left behind. ${ }^{10}$

Although such a worst-case scenario seems far-fetched, the federal center has left nothing to chance, and has taken a flexible approach towards ethnic republics. Trying not to antagonize the leaders of republics any further, Moscow agreed that some members of the Federation Council who had completed their prescribed two terms in office—such as Mintimer Shaimiev—could prolong their stay beyond this limit while offering others seats in the State Council. Some of the presidents, like North Ossetian Alexander Dzasohov or Valery Kokov from Kabardino-Balkaria or Leonid Markelov from Mary El, were wooed with economic incentives and privileges for their republics. ${ }^{11}$ A similar policy was used by Putin's administration toward the regional governors. The regions were given until the middle of 2002 to bring the 42 power-sharing agreements previously concluded with the federal center into compliance with federal laws voluntarily. After that date they could face judicial procedures. This carrot and stick approach largely helped to overcome opposition by regional barons to the federal center. According to Farid Mukhametshin, speaker of the local legislative assembly, even Tatarstan eventually agreed to consider changes in the constitution of the republic that would officially acknowledge that Tatarstan was an integral part of the Russian Federation and not just associated with it. ${ }^{12}$

By reforming the Federation Council and by establishing a strong progovernment faction in the State Duma, Putin succeeded in creating a working majority in both chambers of the parliament. The importance of these changes for the state of national security cannot be overestimated. For the first time in postSoviet Russia, the executive and legislative branches of state power no longer confronted each other in a rigid standoff, a state of affairs that plagued Boris Yeltsin's presidency. Putin's critics labeled this new situation a triumph of bureaucracy over parliamentarianism and even a return to authoritarianism. What actually happened was that the government was given an opportunity to resume the process of political and economic reforms that had come to an almost complete standstill.

\footnotetext{
${ }^{10}$ Putin's address to the Federal Assembly, op. cit.

${ }^{11}$ S. Kez, "Podarennyi Yeltsinym suverenitet - neposil'noye bremya" ( Sovereignty presented by Yeltsin is an excessive burden) Nezavisimaya gazeta, 7 July 2001.

${ }^{12}$ RFE/RL Newsline vol.5, no.180, part 1 (21 September 2001).
} 
In a bid to further streamline the governance process, President Putin proposed to revise the existing party system. By the beginning of 2001, there were 56 political parties and 150 political associations in Russia. ${ }^{13}$ Only a few of them could boast any significant public support and have their representatives elected to regional or federal legislative bodies. Most of them were very small, with only a few hundred or even a few dozen followers. Their programs were often identical. Some of these organizations merely served as a front for vested interests, while others were used by criminal elements. In order to stop this situation of near anarchy, a bill on political parties was introduced into the Duma.

According to its main provisions, new conditions were elaborated for the registration of political parties with the right to participate in regional or national elections. The Federal Justice Ministry was only to register organizations that had ten thousand members or more and that had established branches in at least 50 percent of all regions and republics of the Russian Federation. Other political organizations, groups, or associations would not be required to disband or be prohibited from functioning. However, they would lose the right to enter the election process on their own. In order to do so, they would have to ally with large parties. When the bill on political parties was introduced into the Duma, it met with a strong criticism. One of the main concerns voiced during the debate was connected with a possible threat to civil rights and liberties in society. Concerns were expressed that the bill might, after it became law, be used to restrict the freedom of expression of individuals or small groups and associations. Another possible threat to the political process in the country was seen in the establishment of a requirement for political parties to have a certain number of branches in the regions. This provision, it was claimed by its opponents, could allow manipulation, and could be used to prevent or suspend the registration of a party. However, opponents to the bill could not gather enough votes to overturn it, and in February 2001 the bill passed the Duma in its first reading. ${ }^{14}$

This new legislation on political parties will probably become an instrument of fundamental change in the political life of Russia. Its effects are likely to be several.

First, it has already served to initiate the process of realignment and consolidation among political forces in the country. This may lead to the creation of more distinctive and more easily identifiable party platforms and election programs. This process is by no means easy, taking into account the need to reconcile differing views and ideas while combining what have been autonomous political organizations into a single party. Some results have already been achieved, such as the creation of the SPS. The creation of this united party of rightist forces sends

\footnotetext{
${ }^{13}$ ITAR-TASS, Moscow, 7 February 2001.

${ }^{14}$ I. Rodin, "Dumskiye fraktsii progolosovali za svoyo buduschee" (Duma factions voted for their future), Nezavisimaya gazeta, 8 February 2001.
} 
a signal that many of the small political clubs and associations that mushroomed in the late 1980s and early 1990s have lost their significance, and may disappear completely.

Second, the new legislation on political parties may be used (and many observers of Russian political life believe that this will in fact happen) to strengthen the phenomenon of guided democracy in the country. The term "guided democracy" is understood to mean the formation of a centrist "super party" on the basis of the existing Unity and Fatherland blocs. Such a party, with clear backing from the Kremlin, would dominate the national political arena and enjoy a parliamentary majority. Putin's personal popularity is expected to play a key role in the creation and functioning of such a party, though he himself is unlikely to become its leader. However, even if the Kremlin's interest in having such a party is obvious, it remains to be seen if it can succeed in gathering enough electoral support to be a viable project. One should keep in mind the previous poor performance of similar Kremlin-sponsored, semi-political, semi-bureaucratic formations at national parliamentary elections, e.g., the performance of Yegor Gaidar's "Russia's choice" in 1993 or Viktor Chernomyrdin's "Our home is Russia" in 1996.

\section{National reconciliation and consolidation}

It is almost a platitude to say that a deeply divided society cannot succeed in making progress. The experience of post-Soviet Russia, where public opinion has been deeply split on almost every major issue, is a case in point. It is quite logical therefore that President Putin considered overcoming, or at least mitigating, the political and social antagonisms that exist in Russian society to be a goal of the highest national priority. However, he was very careful in rejecting the resurrection of any official state ideology for these purposes-something that his predecessor had been toying with, albeit totally unsuccessfully. Putin understood that such attempts would only further divide Russian society, rather than unite it. Instead, he called for national reconciliation and consolidation on the basis of universal democratic values as well as national traditions, including patriotism and collectivism. ${ }^{15}$ As one of the first steps in pursuing this goal, Vladimir Putin proposed the adoption of new state symbols. At first glance, they looked like an utterly strange combination. The Russian imperial coat of arms and the white, blue and red flag used by the "Whites" during the Civil War and by democrats when fighting the communists were combined with the music of the Soviet anthem. Taken together, they were meant to be a symbol of an ideologically free continuation of Russian statehood. Initially, this proposal caused heated debates both inside and outside the parliament. Eventually it was approved by an overwhelming majority in both chambers of the Federal Assembly and signed into

\footnotetext{
${ }^{15}$ Vladimir Putin, interview given to ORT and RTR TV stations and Nezavisimaya gazeta, 24 December 2000.
} 
law by Putin in December 2000. ${ }^{16}$ A majority of the Russian population (around $70 \%$ ) also approved and supported Putin's actions on this issue, recognizing them as a call for national unity. ${ }^{17}$

These steps undertaken by Putin were highly important in creating a conciliatory climate in Russian society, but they were rather symbolic in their nature. More concrete measures were undertaken to resolve one of the most socially explosive issues inherited from the Yeltsin period: massive arrears in the payment of wages and pensions to the population. Needless to say, long delays in these payments strongly alienated vast sections of Russian society and severely undermined their trust in democratic reforms. In dealing with this problem, the Putin administration was greatly helped by a substantially improved macroeconomic situation in Russia in 2000-2001. Due to high world oil prices and the after-effects of the 1998 ruble devaluation, Russia's GDP grew by 8.3 per cent in 2000 , and is expected to rise by another 5-6 per cent in $2001 .^{18}$ This allowed the government to allocate part of its increased budget revenues to reduce wage arrears and to increase pensions and wages for state sector employees. As these measures were accompanied by a noticeable improvement in the employment situation, ${ }^{19}$ the number of labor strikes already began to fall at the beginning of 2000. In May-July 2000, no strikes were recorded in the country for the first time in the history of the postSoviet Russia. Some observers even hastened to call these changes a social peace. It was, indeed, a marked achievement in social relations. However, the progress made in this sphere was based on rather shaky grounds and may be short-lived. The current state of the national economy, in spite of its recent growth, is dangerously unbalanced and over-dependent on the production and export of oil and natural gas. Any adverse developments in the world oil market would have a very negative impact on the Russian economy and, by implication, on the whole range of social reforms initiated by Putin.

Not all of the social reforms have been equally successful or popular. A number of new legislative acts on social and economic reforms adopted in the parliament in the first half of 2001 on the initiative of the government generated a great deal of public controversy. Among those acts were the new Labor Code and Land Law, as well as the new legislation on communal services that envisaged the scaling down of government subsidies to the population for housing, electricity, and other communal costs. Introducing them into the parliament, the government

\footnotetext{
16 "Prezident Rossiyskoy Federatsii podpisal zakony o gossimvolike" (President of the Russian Federation signed laws on state symbols), Nezavisimaya gazeta, 27 December 2000.

${ }^{17}$ Results of a public opinion poll published in Nezavisimaya gazeta, 11 January 2001.

18 Interfax, Moscow, 30 April 2001.

${ }^{19}$ In the first eighteen months of 2000-2001, the average size of a pension in Russia increased in real terms by $20 \%$ while the number of unemployed went down by $18 \%$. The wage arrears declined by almost 30\% between August 1999 and August 2001. RFE/RL Newsline vol.5, no.166, part 1 (31 August 2001); vol.5, no. 182, part 1 (25 September 2001); Nezavisimaya gazeta, 5 September 2001.
} 


\section{THE QUARTERLY JOURNAL}

insisted that their adoption was absolutely necessary to complete the breakaway from the Soviet economic system and to bring legislation on labor relations, the land market, and communal payments into compliance with the requirements of a market economy. Indeed, it is no exaggeration to say that by steering these legislative acts through the parliament with the active assistance of the center-right majority there, President Putin and his government have done more to promote liberal market reforms in the country than any Russian government since that headed by Yegor Gaidar almost a decade ago. This, however, may backfire if the reforms undertaken do not help to accelerate economic growth or if vast sections of the population find themselves in a significantly worse condition as the result of an anticipated rise in housing and other communal payments. After all, in spite of all recent economic achievements and social improvements, according to the State Statistics Committee 34.7 percent of the Russian population still have an average income that is dangerously close to or even below the subsistence level. ${ }^{20}$

The mounting public criticism has already been reflected in some regional election results. For example, in July 2001 in Nizhny Novgorod, the third-largest city in Russia, the incumbent governor (actively backed by Putin) lost heavily to his Communist opponent, who was supported by a broad center-left coalition. ${ }^{21}$ The results of a national opinion poll conducted by ROMIR-Gallup International one month later indicated that over 45 percent of the Russian population no longer trust the national government. This came as another disturbing sign of resumed social tensions and increased public discontent. According to the poll, 34 percent of the electorate intends to vote for candidates of the Communist party at the next parliamentary elections, while the main pro-government Unity bloc recorded 25 percent support. ${ }^{22}$

These latest shifts in public opinion do not necessarily mean that the central government is already in serious trouble. However, dwindling support for the government can hardly be ignored, as it may signal a re-opening of wounds only partly healed and a collapse of a temporary social accord. As the result, the earlier tendency towards national reconciliation and consolidation may be threatened and even reversed.

\section{Ensuring the rule of law and order}

As was mentioned earlier, the promise to fight terrorism and separatism in Chechnya and to establish the rule of law there was a key element that allowed Vladimir Putin to sail into the highest public office in the country. Now, two years later, the situation in Chechnya still remains the largest law-and-order problem in the

\footnotetext{
${ }^{20}$ Moscow news 34, 30 August-5 September, 2000, p.7.

${ }^{21}$ L. Andrusenko, "Poligon liberal'nyh reform stal regionom 'krasnogo poyasa"'( Testing ground of liberal reforms became a 'red belt' region) Nezavisimaya gazeta, 31 July 2001.

${ }^{22}$ RFE/RL Newsline vol. 5, no. 167, part I, (4 September 2001).
} 
Russian Federation. Admittedly, during this period the federal government succeeded in crushing large-scale organized military resistance in Chechnya and reestablished its administrative control over the breakaway republic. A no less significant achievement was winning part of Chechen society over to the federal side, particularly in the areas north of the Terek River, and starting a gradual process of devolving some of the administrative duties to local authorities.

These achievements notwithstanding, the hostilities in Chechnya have never stopped. Separatists use hit-and-run tactics, attacking individual federal servicemen and even small military units (including in Grozny, capital of Chechnya), planting mines and other explosive devices on roads and in government offices as well as terrorizing and murdering Chechens that choose to cooperate with the federal authorities. The problem of Chechen refugees, around 150,000 of whom are stranded in neighboring Ingushetia, remains unresolved. The main reason for their refusal to return to their homeland is the inability of the federal authorities to ensure their safety.

Obviously, solving these problems and bringing the situation in Chechnya under effective federal control does not rest with the army any longer. Mopping-up operations against the pockets of resistance remaining there should now be done primarily by specially trained security services. In fact, continuing the use of the army for these purposes has become counter-productive. Heavy weapons, including artillery and air power, either cannot be used against terrorist attacks in cities or densely populated rural areas or, if they are used, the reaction of the local population is, understandably, highly negative. Facing up to these realities, the federal authorities have started the withdrawal of army units from Chechnya. These units are being replaced by police and security services. The latter, however, have yet to prove their ability to cope efficiently with the rebels.

As the conflict in Chechnya is basically a political one, it cannot be resolved by military means alone. This is recognized by the federal authorities, but so far they have failed to come forward with any viable long-term strategy that would include coordinated political, economic, and security measures to deal with the situation in Chechnya. One may only share the opinion of many observers of the conflict in Chechnya that the absence of such a strategy reflects a conflict of vested political and economic interests, both in Moscow and in Chechnya itself. ${ }^{23}$ Obviously, such a situation cannot drag on forever, though it may remain inconclusive for an exceedingly long time. In the wake of the terrorist attacks on New York and Washington, the pressure from Western countries as well as from domestic pacifist groups on the Russian government to search for a political solution in Chechnya

\footnotetext{
${ }^{23}$ For more on this conflict of interests in resolving the situation in Chechnya, see Aleksandr Khalmukhamedov, "How to return to normality in Chechnya" and Larissa Khoperskaya. "The Northern Caucasus: factors of confrontation and prospects for stability," in Chechnya: The International Community and Strategies for Peace and Stability eds. Lena Jonson and Murad Esenov (Stockholm: The Swedish Institute of International Affairs, 2000): 11-20 and 61-74.
} 
was substantially relieved, although this may be only temporary. Moscow used this opportunity to restate its earlier claims that "the events in Chechnya cannot be considered outside the context of the fight with international terrorism." While pledging to continue to deal resolutely with international terrorists, Moscow also stepped up its efforts to resolve the conflict by urging more moderate elements among the rebels to sever contacts with their extremist leaders, disarm, and start negotiations with the federal authorities on their reintegration into the civilian life of Chechnya. ${ }^{24}$ Apart from this, the federal authorities launched a program aimed at improving the interaction between the Russian military and the civilian administration in Chechnya. It remains to be seen whether these new initiatives will help the federal authorities to achieve a breakthrough in the conflict. However, if the situation does not improve substantially before the next presidential elections in 2004, and even more so, if it gets worse, the law-and-order situation in Chechnya may again become a key issue in the new presidential campaign, this time to the detriment of Putin.

\section{Conclusions}

Judging Vladimir Putin's domestic policy in 2000-2001 from the standpoint of its impact on the state of national security, it may be stated that, thus far, it has been relatively successful. President Putin has followed a course of what may be termed "liberal nationalism," which combined mildly nationalistic rhetoric and étatism in administrative matters with a liberal approach to economic issues. Through this approach, President Putin managed to arrest the centrifugal trends-though not all of them-that perilously endangered Russian society and the Russian state over the last decade. One of Putin's singular achievements during this period was that his appeal to national unity and reconciliation met with a positive response among highly diverse sections of the Russian society. Among them are many ordinary people who feel betrayed and let down by other politicians following the decade of erratic reforms that led to their impoverishment, social degradation, and a loss of national prestige. Also among them are the "new rich," who believe that Putin will not reverse the results of privatization or prosecute them for their alleged wrongdoing. The military-industrial establishment can also be counted among the groups to have responded positively to Putin's measures, hoping that under the Putin administration the decline in the state of national armed forces will be stopped and then reversed. Finally, among them is a significant part of the younger generation who believe that Putin understands their needs and concerns much better than elderly politicians who already made their careers under the Communist regime and now merely continue to cling to power.

\footnotetext{
${ }^{24}$ International Herald Tribune, 25 September 2001, p.4; RFE/RL Newsline vol.5, no.182, part 1, 25 September 2001
} 
Working to meet their expectations, President Putin and his government initiated a number of steps addressing the most urgent social, economic, and domestic security problems. Even though, two years later, the record of their actual achievements is rather mixed, that is only to be expected taking into account the huge backlog of economic, social, political, and ideological problems accumulated in Russian society over a number of previous years and even decades. In any case, it is to President Putin's credit that he managed to move the country out of national crisis and onto the road of normal development, as well as to strengthen the basis of national security during this period. However, these are only the first encouraging results.

To succeed further in his mission, President Putin will have to overcome a multitude of political and economic constraints with rather limited resources at his disposal. For that he will need continuing and strong public support, which may easily be eroded if the national economy slips into a recession or if the security situation in Chechnya does not stabilize and improve. It was domestic issues (such as promises to fight Chechen separatism and terrorism, to strengthen Russian statehood, or to impose law on the most arrogant financial barons) that propelled Putin to the highest office in the country and made him so popular in Russia. It will be domestic problems that may again become the most dangerous stumbling block for him if he fails to deliver on his promises of social stability, economic progress, and enhanced domestic security. In Russia, it is not uncommon for public expectations and admiration to easily change into a dramatic loss of trust and rejection. One has only to remember the stories of Mikhail Gorbachev or Boris Yeltsin. 


\section{Bibliography}

Kez, S.. "“Podarennyi Yeltsinym suverenitet - neposil'noye bremya" ( Sovereignty presented by Yeltsin is an excessive burden)." Nezavisimaya gazeta (2001).

Shevtsova, Lilia. Yeltsin's Russia: Myths and Realities. Washington, D.C.: Carnegie Endow- ment for International Peace, 1999.

Tropkina, Olga. "Zakon o formirovanii SF prinyat, teper' delo za prezidentom" (Law on forming the Federation Council is adopted, now it's up to the President." Nezavisimaya gazeta (2001). 